\title{
A Conversation Analysis of Repair Trouble Sources, Inadequacy and Positions in the Iraqi University Viva Discussions in English
}

\author{
Mohammed Jasim Betti ${ }^{1} \&$ Mohammed Abbas Mahdi ${ }^{1}$ \\ ${ }^{1}$ Department of English, College of Education for Humanities, University of Thi-Qar, Nasiriya, Iraq \\ Correspondence: Mohammed Jasim Betti, Prof. \& Ph.D., Department of English, College of Education for \\ Humanities, University of Thi-Qar, Nasiriya, Iraq. Tel: 964-782-750-5317. E-mail: alseady2@gmail.com
}

Received: November 15, 2020; Accepted: November 25, 2020; Published: November 25, 2020

\begin{abstract}
Oral interaction is sometimes not articulated by its participants as perfect as they project. The unsuccessful instances of talk in exchange may cause serious communicative breakdowns between the involved partners of the interactive activity. Conversation analysis (CA) is privileged to have a powerful mechanism, which is called repair organization that is exploited in interaction to prevent and fix any variety of troubles in talk. This strategic organization of repair is then operated to capacitate talkers of unavoidable interactive breakdowns of talk.

Accordingly, this study aims at observing, describing, analyzing and identifying the trouble sources of repair strategies which exist in the Iraqi university viva discussions in English, and investigating their repair positions and inadequacies. Likewise, it is hypothesized that misunderstanding errors is the most frequent trouble source of repairs in the Iraqi university viva discussions in English, non-repair is the most frequent repair inadequacy, and that the fourth position of repair is the most frequent position type.

The procedure adopted to fulfil the aims and to verify the hypotheses include collecting data which consists of four hours and ten minutes of audiotaped oral interactions in the MA and Ph.D. viva discussions, developing a model for repair strategies from various theories in CA, observing and collecting the data by recording audiotaped samples of those interactions in viva discussions as sample of the study, putting the datasets into orthography, calculating and describing by the use of the model, and analyzing the dataset of the study qualitatively and quantitatively.

The study concludes that the eclectic model suggested and applied in the study gives a multi- faceted description of the different repair study. It is found that repair sources of trouble include grammar, vocabulary, pronunciation, discourse, factual information, channel, processing, misunderstanding errors, repair of no errors. It also exposes that there are zero occurrence of miss-repair, self-repair and other-repair failures, that pronunciation trouble source of repair results in the highest occurrences and that factual information and repair of no errors are the least frequent trouble sources. The study reveals that non-repair is the most frequent repair inadequacy and same turn repair position is the most frequent one.
\end{abstract}

Keywords: CA, Trouble Sources, Repair Inadequacy, Repair Positions, Viva Discussions

\section{Introduction}

Language is a means of communication between interlocutors, which is sometimes hardly delivered by its partakers as faultless as they anticipated (Feltner, 2016, p. 1). Participants of any talkative activity may encounter frequent occurrences of "disfluencies e.g. "umms," "ahhs", "hesitation markers", "misarticulations", exploitation of "a wrong word", inaccessibility to a word if looked-for, "failure to hear or to be heard", and inappropriate understandings by receivers, or some other talk troubles, etc. (Sert, 2015, pp. 88-89; McTear et al., 2016, p. 42; Tracy 2020, p. 203). This is because the act of talk is not a simple interconnected two-way activity of speakerhearer in which communicators are talking to conveying meanings. It is rather a more complicated phenomenon of mutually cooperative action done to achieve and to organize meanings, which is of extremely meaningful objectives (Hutchby and Wooffitt, 2008, p. 1). Such a joint or two-way talkative activity indicates that the process of talking is participant dependent.

From a theoretical point of view, talk is a rapid and progressive action, which is not to be interrupted unless an emerging problem appears, and from a practical point of view, talk is full of troubles, which hinder talkers to proceed with such a persistent uninterrupted sense of talk (Couper-Kuhlen and Selting, 2018, p. 112). As a result, 
such a trouble may explicate that any instance, which impedes the continuous meaning-making of mutual understanding, seems to be dispreferred and the participants are of instantaneous need to be terminated and fixed at once (Bazerman, 2012, pp. 228-229). However, the unsuccessful instances of talk in exchange may cause serious communicative breakdowns between the involved partners of talk. The process of establishing comprehensible communicative signal transmissions is a criterion for any fruitful interactive activity and it is indispensable to any parties of talk. Conversation is privileged to have a powerful mechanism, which is called repair organization that is exploited in interaction to prevent and to fix any variety of troubles in talk. This strategic organization of repair is then operated to capacitate talkers of unavoidable interactive breakdowns of talk (Moore and Arar, 2018, p. 9).

Accordingly, repair is a substantial technique to maintain the continuity of conversation if it is disintegrated by some troubles in speaking, hearing or understanding, etc. (Bergmann and Drew, 2018, p. 6). Thus, repair can be considered a problem solver since it assists the learners' capability of the interactional adjustments and it is of a pivotal role in solving problems of speaking, listening, and hearing, etc. (Kusey, 2016, p. 1-2). To the best of the researcher's knowledge, no study inside Iraq is conducted about repair in the Iraqi university viva discussions. Accordingly, the study tries to address the following research questions:

1. What are the trouble sources that trigger the instances of repair in the Iraqi university viva discussions in English?

2. Are there repair failures, non- repair or miss-repair in those viva discussions?

3. What are the different positions of repair strategies in the discussions?

It is hoped that this study is of value to teachers to incorporate repair strategies in classroom interaction as a remedial act whenever communicative breakdowns happen, to assist them in discovering the techniques, which could be of a corrective significance to any communicative breakdown activity and to pinpoint the trouble sources of language to be repaired, the repair inadequacy and repair positions. It is hoped also that it may assist textbook and curriculum designers to give more emphasis on providing activities that enhance the use of repair which have a central role that supports the continuous progressivity of talk.

The study sets to achieve the following aims:

1. Constructing a model for repair strategies to describe the data in the Iraqi university viva discussions in English, which is taken from representative authors and writers.

2. Identifying the trouble sources of these strategies of repair in the data.

3. Identifying the repair inadequacies and positions in the data.

4. Providing a qualitative and quantitative analysis of repair in the data.

The hypotheses of study include the following:

1. Misunderstanding errors is the most frequent trouble source of repairs in the Iraqi university viva discussions in English .

2. Non-repair is the most frequent repair inadequacy in the discussions.

3. Repair is more frequent than non-repair in the data.

4. The fourth position of repair is the most frequent position of repair in the data.

The study adopts the subsequent procedure to fulfill its aims and to verify its hypotheses:

1. Developing a model for repair, which is taken from a variety of theorists and writers, to be applied in the description of the Iraqi university viva discussions in English.

2. Collecting the data by recording some audiotaped samples of the interactions of viva discussions in English and putting it into orthography .

3. Observing, describing and analyzing repair source troubles, inadequacies and positions according to a special developed framework of the study.

\section{Literature Review}

\subsection{Conversation Analysis}

The foundation of CA goes back to the pioneering studies done by Harvey Sacks, Emanuel Schegloff, and Gail Jefferson in the 1960s to 1970s. Fundamentally, CA is well motivated and originated through the influence of sociology. Since that, it is developed as an interdisciplinary nature with fields such as anthropology, psychology, communication, cognitive science, evolutionary theory, education, clinical research and practice, and electrical 
engineering (Clift, 2016, xv; Hoey and Kendrick, 2018, pp. 151-154). CA is one of the approaches, which deals with social interaction. Several definitions of CA are proposed. Generally, it is "the study of talk". More particularly, "it is the systematic analysis of the talk produced in everyday situations of human interaction: talkin-interaction" (Hutchby and Wooffitt, 2002, pp. 13-14).

It is remarkable to outline the technicality of both CA and discourse analysis. In this regard, both notions have some different and similar key principles. From this perspective, there is closeness in the field of investigation of everyday interaction and thus they are similar in the talk, which is subject to investigation, along with, all the characteristics and details of data, which are significant (Wooffitt, 2005, pp. 71-73). Discourse analysis is not just the study of language. It is a way of looking at language that emphasizes how people use it in real life to do things, such as jokes, argument and persuasion, and to show that they are particular sorts of people or belong to certain groups (Betti and Hashim, (2018, p. 279). "Text and discourse apply equally to speech and writing in spite of some tendency to associate text with writing and discourse with speech. In fact, though writing and speech may differ in many ways, they share the same structure" (Betti, 2007, p. 400).

Conversation analysts believe that it is highly important to study everyday conversation in different contexts since firstly, it is the basic communicative device in different organizations and different institutional settings by which our lives are based on, secondly, for finding out the model of interaction of people at all times and contexts (Garcia, 2013: 7). Another salient feature of the methodological orientation of $\mathrm{CA}$ is the naturalness of data, which necessitates the actuality of talk; this means that gathering data through "interviewing techniques, observational methods, native intuitions, or experimental methodologies" is not allowed or strongly dispreferred, since this violates the sense of being natural in collecting data. Thus, this can be done mainly through audio or video recordings of naturally generated data. It is a fact that CA is extremely dependent on naturally occurring data, which necessitates transcribing small details of the talk (Wong and Waring, 2010: 4). One consequence of such methodology is that the data must be systematically transcribed with the special distinctive system because such natural data is extremely rich with details (Bergmann and Drew, 2018, pp. 1-7).

In this regard, turn-taking refers to "the change from one speaker to another in conversations and dialogues. Turntaking is made possible by a verbal or nonverbal bid, e.g. so that's what we're going to do, that's was all I wanted to know, that's fine ... or by completing an initiating act, or by gazing or looking at the listener" (Betti and AlJubouri, 2015, p. 307).

\subsection{Definition of Repair}

To Schegloff, et al. (1977, p. 361), repair operates in conversation, addressed to recurrent problems in speaking, hearing, and understanding". Similarly, some parallel definitions of repair are presented. For instance, Fox and Jasperson (1995: 80) define repair as "any instance in which an emerging utterance is stopped in some way, and is then aborted, recast, or redone". Sidnell $(2010$, p. 110) acknowledges the designation of repair as being a set of practices through which the participants of conversation can treat and potentially fix problems of speaking, hearing, or understanding. Further, Hayashi et al., (2013, p. 9) define the organization of repair as "a set of systematically organized, party-administered practices through which a conversation's participants manage such inescapable contingencies". Egbert (2017, p. 167) considers repair as a conversational mechanism, which indicates and fixes troubles of speaking, hearing, or understanding conversation. However, the term repair shows an indispensable need to be exactly clarified. The word repair is widely acknowledged by researchers, in terms of its acceptability, as a cover term to communicative breakdowns (Alzaidi, 2016, pp. 20-22).

Likewise, Tye-Murray (2020, p. 163) presents a recent conclusive description of repair strategies as being tactics available to the participant to rectify communicative breakdowns in conversation. This means that repair strategies are ways for remedying any communicative trouble. This magnifies the domain of repair strategies to a wider layer in communication.

Another significant implication of the wide scope of repair's definition is that "repair" is used rather than "correction" because "correction" is meant to refer to the process of replacement of an "error" or "mistake" to what is correct. This term is preferred to cover all the communicative breakdowns of conversation and for its sense of wide applicability to all domains of interactions. Moreover, repair "[is] neither contingent upon error nor limited to replacement" (Schegloff and Sacks, 2018, p. 95).

Schegloff et al., (1997, p. 381) consider repair as "the self-righting [self-correction] mechanism for the organization of language use in social integration". This means that it is an indispensable apparatus for wellorganized social interaction. For that reason, repair practices can be utilized to fix such troubles and to maintain a mutual understanding (i.e. intersubjectivity) which is "locally organized, recipient designed and subject to local, sequential, contextual, environmental, and organizational contingencies moment by moment". This shows the 
crucial necessity for maintaining intersubjectivity (i.e. mutual understanding) (Hayashi et al., 2013, p. 9; Robles, 2017, p. 59).

Mechanism of repair is of two main forms; firstly, it is a conversational one that functions in common purposes and contexts of interaction. Secondly, a didactic one, which is similar to the above-mentioned one but it, has a pedagogical nature (Nassaji, 2015, p. 93). Repair mechanisms have a meaningful part in both everyday conversation and classroom conversation.

\subsection{Types of Trouble Sources}

It is a fact that interaction is full of errors, imperfections, clarifications, mishearings, and slips, etc. Seedhouse (2004, pp. 159-164) believes that repair mechanism in the classroom has a reflexive correlation in the middle of pedagogy and interaction. As such, he contrasts repair mechanisms in three types of classroom contexts, which are "form-and-accuracy contexts, meaning-and fluency contexts, and task-oriented contexts". It is found that repair is in form-and-accuracy context overpoweringly initiated by the teacher to the learner who is the producer of the trouble (Seedhouse, 2004, p. 142).

In such contexts, the teacher may preserve any errors alike to phonological, syntactical, or pragmatic misuse as trouble and thus such repairable must be repaired. Moreover, repair is in meaning-and-fluency context is a device to maintain intersubjectivity. In such contexts, overt correction is to be carried out simply if there is an indispensable error, which slows down the process of communication. Finally, repair of a task-oriented context is much oriented towards the achievement of the task (Tateyama, 2012, p. 82). There are types of errors, which cause trouble in conversation. Dulton-Puffer (2007, p. 220) presents descriptive categories of erroneous troubles sources, by introducing some types of errors, which show an indispensable need to be repaired. These are errors are of grammar, vocabulary, pronunciation, discourse, factual, channel, and processing, these categorization of trouble sources are as follows (Kääntä, 2010, p. 71).

\subsubsection{Grammar}

This category contains the morphosyntactic errors, which in return encompasses the morphological and syntactic errors (Tsuchiya, 2016, p. 183). This category is involved in the wrong selection and violations of the morphosyntactic errors, which can result in erroneous generations of grammatical structures. The syntactic errors include misusing articles, the $3^{\text {rd }}$ person singular "s", tenses, negation, past participles and relative clauses (AlSeady, 2002: 18). Moreover, the extracts of the study are utilized to exemplify a certain aspect of repair and they encompass wide-ranging contexts in that they may involve native or non-native speakers inside or outside the classroom:

Extract 1 (Roshan, 2014, p. 67)

$01 \mathrm{~A}$ : The age is a matter that which we put behind.

This extract shows how the wrong selection of a grammatical word is done and how it is repaired. It also shows that the speaker of this utterance generates a grammatical trouble, which is then repaired to a constituent that fulfils the needs of being accurately intelligible meaning-making sense.

\subsubsection{Vocabulary}

This category contains lexical errors of types of wrong denotation, idioms, technical terms, wrong stylistic choice (Smit, 2010, p. 183).

Extract 2 (Kormos, 2000a, p. 167)

$01 \mathrm{~A}$ : Will er have to pay er five er sorry er twenty-five percent.

This extract shows a wrong selection of words by which the speaker uses "five" instead of "twenty-five". Therefore, the speaker initiates a repair after noting the committed error.

However, Van Lier, (1988, pp. 187-188; cited in Seong, 2006, p. 231) displays a contextual sense of classroom repair in which non-native speakers exploit repair with special sense. As such, repair can be message-oriented repair which concentrates on the "transmissions of thoughts, information, feelings", etc. (Shintani, 2016, p. 96). This next extract takes place between elementary students of EFL classroom:

Extract 3 (Van Lier, 1988, p. 188 cited in Cho 2008, p. 21-22)

$01 \mathrm{E}$ : what do you think is the main problem in the future.

$02 \mathrm{~F}$ : in the future.

$03 \mathrm{E}: \mathrm{m}:$ 
$04 \mathrm{~F}$ : listening to the class an: technical words

$05 \mathrm{E}:$ [m:?]

$06 \mathrm{~F}$ : como? ((tr: what?))

$07 \mathrm{~F}$ : technical words

$08 \mathrm{E}$ : technical words

\subsubsection{Pronunciation}

Smit (2010, p. 183) states that this category contains some instances of phonologically based errors like wrong word stress and major phonemic substitutions or mispronunciations:

Extract 4 (error of phonemic mispronunciations, Krause, 2000, p. 78)

$01 \mathrm{~A}:$ with the gleat ${ }^{\wedge}$ the great glass elevator

This extract shows how the speaker initiates repair after a mispronunciation or phonemic exchange of the word ("great", pronounced as /gleat/). Therefore, he replaces the mispronounced word with the correct one by saying ("great", pronounced as /greit/):

Extract 5 (error of slip of the tongue, Burford-Rice and Augoustinos, 2017, p. 12)

01 Pang: And that is another young defense (.) whenever they say that PK Subban's the best 21 year old defense man .hhh Alex Pietrangelo also represented Canada he's a 21 year old .hhh, he's a first round pick .hhh and he does everything .hhh on the ice, off the ice the white way .hhh the right way

The speaker of the previous extract repairs his slip of the tongue in which he replaces the utterance from "the white way" to "the right way". The following extract shows the error of wrong word stress (Gilbert, 2008, p. 5):

Extract 6

01 Student: Mrs. Stiebel, can you help me with comedy?

02 Teacher: Comedy?

03 Student: Yes, comedy is a big problem.

04 Teacher: I don't quite follow.

05 Student: (Patiently) Problem - this is worry.

06 Teacher: Yes, a worry. Um .... You mean a problem with comedy on TV?

07 Student: TV? (Trying again). The boss put me on department comedy, all the time they argue.

08 Teacher: Oh, you mean committee!

09 Student: Yes, what I told you, comedy.

This extract verifies the significance of word stress and the way it can result in a communication breakdown when it is put inappropriately. It is very noticeable that the source of misunderstanding causes the misplacement of word stress. The stress of the word committee that the student aims to articulate is on the second syllable, /kə'mit $\mathrm{i} /$. Nevertheless, the student articulates it with the word (comedy) since he substitutes the stress on the second syllable with the first syllable as it is in comedy /' kpm I di/ (Aktuğ, 2015: 17).

\subsubsection{Discourse}

Dulton-Puffer (2007, p. 218-220) states that this category contains some inaccuracies of unsuccessful or unwarranted topic shifts, developments, or difficulties, which cause problems in the turn-taking system. To be more precise, it contains some occurrences, which impede the smoothness of unfolding discourse. However, this category can be defined as an erroneous one that disturbs the state of being coherent or cohesive in discourse. Such a category of trouble is infrequent. A simpler version of this wide-scope definition is the sense of generating incomplete or overtly complex sentences.

Extract 7 (Kormos, 2000b, p. 382)

$01 \mathrm{~A}$ : in this case er if it is so urgent and important for you, we would like er you to:: to write us an orderer in er 24 hours that you make sure that you will er come and book this eel room.

02 B: I see, all right and then I can only pay the deposit next week when I er find out how many people come and when I have talked to all of the people.

$03 \mathrm{~A}$ : Er but this letter is er-the order-er your request is er anyway-needed and we::: 
This lengthy extract shows the use of too long sentences instead of shorter ones. It also shows a little smoothness of discourse for expressing the central idea of the extracts, which is the phrase "the order". However, the speaker goes too far by choosing firstly incoherent terminology of the phrase "this letter", which is repaired later. In the midst, of this lengthy extract, the speaker uses the phrase "the order" at the first turn, which is later being replaced with the wrong terminology by saying "this letter". Then, the speaker decides once more to repair this incoherent terminology with a more coherent one.

\subsubsection{Factual Information}

This category contains instances of wrong dates or figures and it is not easily distinguishable from lexical errors. The distinguishability of "factual information" category from "vocabulary" category, can be seen through the selection of date and figures in "factual formation" category and lexical errors in "vocabulary" category (DultonPuffer, 2007, p. 220).

Extract 8 (Roshan, 2014, p. 72)

$01 \mathrm{~A}:$ On Saturday there is a lecture...no no on Sunday.

This extract shows that the speaker inaccurately selects a wrong date by saying "saturday", which is then replaced and repaired with an accurate one by saying "sunday".

\subsubsection{Channel}

Dulton-Puffer (2007, p. 220) shows that this category contains types of channel trouble sources of problems of hearing or speaking either too noisy or too soft, which can result in non-hearing of mishearing. Extract (8), for mishearing (i.e. soft hearing), and extract (9) (for mishearing of speaking or non-hearing at all), show the effect of channel respectively:

Extract 9 (Carterette \& Jones, 1974, p. 418)

$01 \mathrm{~A}$ : I thought you had a date with your boyfriend to go to a party.

02 B: No I went to a shower.

$03 \mathrm{~A}: \rightarrow$ To a where?

04 B: I went to a shower.

The second turn above is problematic to participant " $\mathrm{A}$ " because he mishears what he says so " $\mathrm{A}$ " initiates a repair by saying "To a where ?".

Extract 10 (Schegloff et al., 2003: 250)

\section{$01 \mathrm{~A}: \quad$ Wul did'e ever get married'r anything?}

02 B: $\rightarrow$ Hu:h?

03 A: Did jee ever get married?

04 B: $\quad$ I have // no idea.

The utterance "Hu:h?" shows that participant "B" does not hear the question in the first turn. This necessitates participant A's repeating the question. Thus, repair participant "B" initiates the procedure of repair at this turn by saying as indicated by the arrow " $\rightarrow$ Hu:h?". However, this may be attributed to the fact that the participants are in a certain environment where even if you speak loudly, the other participant may mishear you because there it is too noisy around you (Robin, 2006: 42-43).

\subsubsection{Processing}

Roshan (2014, pp. 62-63) states that the category of processing errors contains incomplete sentences, construction changes, and reformulations:

Extract 11 (Ibid, p. 72)

$01 \mathrm{~A}$ : I think last term I told it to you...last terms

This extract is repaired through reformulation and addition of plural "s" or repetition with the addition of plural "s" from its original trouble sourced version "term" to "terms".

\subsubsection{Misunderstanding Errors}

Frankel and Wood (2011, p. 90) define misunderstanding as the listener's inaccurate interpretation of the utterance accompanied by a lack of knowledge of the interpretation, of the speaker's intended utterance. 
Extract 12 (Schegloff et al., 1977, p. 366)

01 Ann: Which one::s are closed, and which ones are open.

02 Zee: Most of 'em. This, this, //this, this ((pointing to map)]))

03 Ann: $\rightarrow$ I 'on't mean on the shelters, I mean on the roads.

04 Zee: Oh.:

The extract shows Zee producing a wrong answer to Ann's question because Zee misunderstands Ann's question "Which one::s are closed, and which ones are open" about the shelters. Then, Ann repairs the misunderstanding in the later turn by saying "I 'on't mean on the shelters, I mean on the roads" (Ibid).

\subsubsection{Violation of Social Norms Errors}

This category refers to the violation of the rules of politeness or other established social rules. For that reason, the participant may fix his utterance to get rid of the consequences of such a violation. The following adopted extract of Garcia (2013: 109; cited from Jefferson, 1974, p. 184) shows this clearly:

\section{Extract 13}

\section{A: I told that to THUH- UH- officer. [At an American courtroom]}

This extract takes place at an American courtroom whereby the formality and shared knowledge necessities the speaker (A) to employ special words to fit the situation. However, it has crucial indications for the violation of the social norm. The use of hesitation markers such as ("UH" uh) indicates that the utterance is being edited in that there is a mismatch between the utilization of "THUH [i.e. the]" which is usually pronounced as /ठə/ before consonants and the word officer. This indicates that the speaker tries to say cop instead of officers but he replaces the word cop in favor of the word office since the formality of the situation necessitates not belittling the judge of the court by using informal language. The second indication is the articulation of "the" as / $\mathrm{\partial a/}$ instead of the articulation of "the" which is usually pronounced as /ठi/ before vowels which is the anticipated utterance he would say (Garcia, 2013, p. 109).

\subsubsection{Repair of Inaudible Error}

Schegloff et al. (1977, p. 363) explicate that this type of repair refers to repair of no hearable error, mistake, or fault at all. This type shows no obvious error or something, which disturbs the smoothness of utterance. As such, the speaker decides to self-edit the grammatically correct form to the more intended one. The following extract shows this:

Extract 14 (Schegloff and Sacks, 2018, p. 96)

01 Ken: $\rightarrow$ Sure enough ten minutes later the bell $r-$

$\rightarrow$ the doorbell rang...

For the sake of preciseness of the word choice, "Ken" decides to self-edit and replaces the word "bell" by "doorbell". The purpose of such selection may be attributed to stylistic choices (Cho, 2008: 14-15). This category captures another conceptual facet of the domain of repair; which has a noticeable trouble source without repair initiation (Ibid).

Extract 15 (Roshan, 2014, p. 73)

$01 \mathrm{~A}$ : do you borrow me your cell-phone, I want to make a phone call.

This extract shows how the speaker commits some errors by leaving the sources of the trouble unrepaired. One of them is the use of "do you" instead of "can you" which is left unrepaired. Another one is the use of "borrow" which has the sense of receiving something from somebody instead of using "lend" which has the sense of giving something to somebody.

\subsubsection{Repair of No Errors}

Schegloff and Sacks $(2018$, p. 96) consider this type as another similar version of repair of inaudible error. This type refers to a repair, which contains no error, in that there is no indication of any error or something, which disturbs the smoothness of the utterances. However, it appears that the previous type of trouble source in the previous extract is done by replacing the trouble source with an accurate one while this extract is done by means of a different strategy, which is a word search.

Extract 16 (Schegloff et al., 2003, p. 244)

Olive: $\quad \rightarrow$ Yihknow Mary uh:::: (0.3) oh:: what was it. 


\section{$\rightarrow$ Uh:: Tho:mpson.}

This extract shows that Olive is searching for the name of an individual. It appears at the first turn that she initiates some unfruitful repair strategies by saying "Yihknow" which is then being replaced by "Mary uh::::." with a vowel lengthening and pause in that she says "uh:::: $(0.3)$ oh:: what was it". Later, repair is done by finding the name of this individual that is called "Thompson" as the arrow indicates in Olive's utterance in which she says "Uh:: Tho:mpson." (Robin, 2006, p. 42-43).

\subsubsection{Imagined Mistakes}

Schegloff and Sacks (2018, p. 96) mention that this type of erroneous troubling source contains no obvious linguistic error or something, which disturbs the smoothness of the utterance; rather it contains a predetermined and/or cognitive or memory-based error. In other words, the speaker has certain information about something, which he considers as correct but later after his engagement in conversation with other parties. However, this gives later the impression of being wrong with a need to be repaired:

Extract 17 (Schegloff et al., 1977, p. 369)

$01 \mathrm{~A}:$ I have a: - cousin teaches there.

02 B: $\rightarrow$ Where.

03 A: Uh: Columbia.

04 B: $\rightarrow$ Columbia?

05 A: Uh huh.

$06 \mathrm{~B}: \rightarrow$ You mean Manhattan?

07 A: No. Uh big university. Isn't that in Columbia?

The above extract shows that participant "A" is disorderly mixing up the name of the place "Colombia" as a country with the same name as a university. Therefore, Participant "B" initiates a repair in the fourth turn by saying interrogatively "Columbia?" and in the sixth turn by saying "You mean Manhattan?". The repair is done here because participant "A" assumes that there was be a mistake (Robin, 2006: 46-47).

\subsection{Repair Inadequacy}

Roshan (2014: 73) introduces the notion of repair, which designates the incapability of the talker to generate appropriate outputs; this notion is of two varieties which are non-repair and miss-repair:

\subsubsection{Non-Repair}

This variety describes the incident in which the speaker abandons the error unnoticed (Roshan, 2014: 73):

\section{Extract 84}

$01 \mathrm{~A}$ : She is talking about people who are living in the country but they cannot speak the fluently even ten years. The speaker in above extract abandons the utterance unrepaired.

\subsubsection{Miss-Repair}

This variety explicate the incident in which the speaker attempts to execute self-repair but the endeavor is of no avail in that the speaker generates another error and lets the utterance without repair (Roshan, 2014: 73-78):

\section{Extract 85}

1. A: Yeah, chain...it is a chained restaurant.

The above extract shows that the speaker miss-repairs the utterance two times.

\subsection{Failures of Self and Other-Initiations}

Failure is the incapability of repair practice to generate a positive outcome although the normal procedures of initiating repair are completed. Accordingly, failures in self-repair initiation and other-repair initiation denote the realization of a repair procedure in which failure designates the ineffectiveness of repair, to perform its procedures. Thus, self and other-initiation of repair may generate failures, which are of two cases; failure of self-initiation and failure of other-initiations (Robin, 2006: 46-47):

\subsubsection{Failure of Self-Initiation}

The following extract demonstrates the failure in of self-initiation of repair (Schegloff et al. 1977: 365): 


\section{Extract 82}

01 A: C'n you tell me-(1.0) D'you have any records

$02 \rightarrow$ of whether you-whether you-who you sent

$03 \rightarrow$ Oh(hh) shit.

04 B: What'd you say?

$05 \mathrm{~A}$ : I'm having the worst trouble talking.

This extract shows that (A) is having a trouble, which causes him to repair, but he fails in doing so. The first turn is problematic and for that reason, (B) generates the practice "What'd you say?" to get a repaired answer. Once again, (A) miscarries to repair his trouble by stating that he is not able to express himself "I'm having the worst trouble talking".

\subsubsection{Failure of Other-Initiation}

The following extract demonstrates the failure of other's initiation of repair (Schegloff and Sacks, 2018: 99):

\section{Extract 83}

01 Roger: It's kinduva- // kinduv weird.

02 Dan: heh (2.0)

03 Roger: Whadda you think?

04 Ken: $\rightarrow$ Hm?

05 Roger: $\rightarrow$ Forget it.

The fifth turn above shows that Roger is incapable of repairing his previous talk. This causes Ken to generate an open class practice (Hm?) to get extra information.

\subsection{Positions of Repairs}

Self-repairs has some locations in the turn-taking system. The locations of repair function as an indicator to the process of repair initiation which may take place in different places in the turn-taking system such as first-turn repair, same-turn repair, transition-space repair, third-turn repair or third position repair, etc. (Couper-Kuhlen and Selting, 2018:114; and Heinemann and Steensig, 2018:452). Accordingly, the locations of self-repair are as follows:

\subsubsection{Same-Turn Repair}

This is the first location, which deals with conversationally occurring problems in "the same-turn as the trouble source". The frequency of this type of repair in conversation is higher than the other types of repairs. This location of repair is privileged with a diverse set of operations that take place seamlessly within the same turn, which has significant repair structures (Schegloff et al., 2003:248; and Schegloff, 2013:40-43; and Tang, 2014:105). The following extract demonstrates this:

Extract 34(Liddicoat, 2011:214)

Anna: oh so then he is coming back on Thur- on Tuesday.

This extract demonstrates how same-turn repair takes place through repairing and replacing the trouble source (Thur) with (Tuesday) in the same-turn as the trouble source.

\subsubsection{Transition-Space Repair}

This is the second location, which involves a process of fixing a self-trouble source of the speaker himself. It occurs at the very first possible completion of the turn, which contains the trouble source, or it may occur after the turn, which contains the trouble source (Liddicoat, 2007:187). The following extract demonstrates this:

Extract 35(Jefferson, 2007:446)

01 Clara: I thought you weren't going to stop at that green light.

02 Clara: $\rightarrow$ I mean red light.

It appears that the trouble source in this utterance is finally positioned in which the speaker uses the word (green light) which seems a problematic one in the first turn. The final position of the trouble source is the normal position of this location. Later, the speaker continues her turn at the first possible completion of the turn by initiating and 
repairing the trouble source with repair outcome, which is the word (red light). This location may have no repair initiator or something, which indicates the trouble source (Liddicoat, 2007:187):

Extract 36 Schegloff (1997b: 36).

B: -then more people will show up. Cuz they

$\rightarrow$ won' t feel obligated to sell, tuh buy

\subsubsection{Third-Turn Repair}

Third-Turn Repair can be used to repair trouble sources of the utterance in its third turn. The intervening turn between the first and third turns may show no problem with the previous turn. Usually, the first turn of this type of repair contains the trouble source while the third one contains the repair initiation and completion (Schegloff et al., 2003, p. 249; Kitzinger, 2008, p. 186; Kitzinger, 2013, p. 246).

Markee (2009, p. 95) argues that third-turn repair is to be produced when the speaker finds out that the produced talk in the first turn is superficially "adequate". Therefore, the listener may treat this as not being a trouble source. However, the speaker goes once more to repair his prior talk. This can be done by the speaker without prior notification to the listener:

Extract 38 Jefferson (2007:450)

01 Bess: . . . her money isn't finite,

02 Gail: Uh huh

03 Bess: I mean infinite.

04 Gail: Oh right right!

Bess in the first turn uses the word (finite), which is to be considered as a trouble source later. Gail uses (Uh huh) to convey the fact that there is no problem with the former turn. Later Bess comes back to initiate her first turn by say (I mean infinite) which seems more intended and the one that the speaker means. This also shows a sense of inadequate response to Bess's own turn, which necessitates him, to repair what is more appropriate (Wong and Waring, 2010, p. 223).

\subsubsection{Third-Position Repair}

Third-position repair functions as devices to avert and correct misunderstanding trouble source turn in accordance with the response of the next speaker. As such, it provides teachers, students, linguists, or researchers with visions about the ways by which participants use language to address misunderstanding and other crucial related phenomena (Wong and Waring, 2010, p. 224-226; Kitzinger, 2013, p. 247).

However, it is explicitly activated by special intervening turn between repair initiation in the first troubling turn and the third turn of its outcome. A third-position repair has four components for initiating third-position repair, in a case if they are all present, they have the following order from (1)-(4) (Liddicoat, 2007, pp. 196:197; Ekberg, 2012, p. 375):

(1) Repair-initiating component (optional): e.g., no; no, no, no; oh; oh no; oh yeah; well.

(2) Acceptance/agreement (most optional): e.g. I know, I realize that too, that's OK, Oh I know.

(3) Rejection of misunderstanding (optional): I don't mean that, I'm not X-ing, That's not what I mean.

(4) Repair proper (most likely to be present): e.g., I mean Y.

The following extract shows third-position repair (Wong and Waring, 2010:225):

\section{Extract 39}

$01 \mathbf{H}: \rightarrow$ Let me tell you. Everybody really had an

02 evening last night.

$03 \mathrm{C}: \rightarrow$ Oh really. Where did everybody go.

$04 \mathrm{H}: \rightarrow$ Well I mean everybody that went anywhere.

05 C: Oh.

This extract shows a verbal problem, which the third-position repair is designed to solve as it is related to the incorrect reference. As such, the word (Everybody) in the first turn is problematic and for that reason, it is to be considered as a trouble source. The speaker $(\mathrm{C})$ misunderstands the speaker $(\mathrm{H})$ 's reference to the word 
(everybody). Later, speaker (C) produces an intervening turn to show a problem with the previous turn. Consequently, he starts to initiate the process of repair to clarify by saying (well I mean) then continues the process by saying, (Well I mean everybody that went anywhere). Subsequently, it becomes by proof that the participant (C) concludes that the intended idea is now clearer and there is no more miscomprehension (Ibid).

\subsection{Positions of Other-Initiated Repairs}

Other-repairs have two possible locations, which are second and fourth position repair:

\subsubsection{Second Position Repair}

The second position location to other-repairs is the typical sequential structure, which consists of trouble source in the first turn and repair initiation and repair outcome or completion in the second and the third turns. The location of this type of repair indicates that there is a problem with the former turn. In other words, a repair of such type ranges over two turns namely the initiation turn, which is the second turn, and the completion one, which is the third turn (Liddicoat, 2007: 189-193).

This means that the mechanism of second position repair is in the second turn following the trouble source, which is initiated by the recipient of the trouble source (Pasfield-Neofitou, 2012: 181). This location of repair is intended to show that the receiver of the first turn is encountering a trouble, which is in need to be repaired next. Therefore, speakers can use a set of turn constructional devices such as (huh?, questions words alike to what, who, where or when, etc., partial repeats format, you mean format, etc. Dehé, 2015: 189-191):

Extract 56 Liddicoat (2011:226)

01 Harry: Aren' t you suppose to go up there with John though?

02 Joy: What?

03 Harry: Aren' t you goin' up there with John.

04 Joy: Na:h that fell through weeks ago.

The above extract indicates the source of the trouble of the first turn to what follows since this solicit Joy to initiate a repair procedure later. As such, in the second turn, Joy uses the interrogative word (what?) to indicate this trouble with the first turn. Later, in order to complete the repair procedure, Harry repeats some turn constructional units to provide more illustrations. Finally, the fourth turn utilizes extra confirmation for running the exchange smoothly (Liddicoat, 2007:189).

\subsubsection{Fourth Position Repair}

The fourth position repair is characterized by its uncommonness since most of the repairs can be done before this position (i.e. the fourth turn) (Liddicoat, 2011, p. 243). It provides the receiver of the trouble source with a chance of repairing problems of understanding, which results from a noticeable trouble in the structure of the utterance of the third turn (Liddicoat, 2007, pp. 206-209).

However, there is a slight difference between the third position repairs and the fourth ones. Accordingly, the third position repair provides a chance to the speaker of the trouble source to fix the problem of understanding, while the fourth position repair provides a change to the receiver of the trouble source to fix problems of misunderstanding as well (Moore and Arar, 2019, p. 38).

The fourth position repair consists of two components, which are, firstly a modification of state token (oh) reflecting a new understandable consideration of the talk underway, and secondly a redescription of the trouble source addressing the problem of misunderstanding. As such, the process of reanalysis of the trouble source such as in the following utterance (you want one) to (you want my daddy) is typically followed by confirmation of the speaker of the trouble source. This confirmation brings about a different reaction to the trouble source. However, the characterization may not be required in addition to the obligatoriness of "change of state token" that may be included (Liddicoat, 2007, pp. 206-209):

Extract 57 (Schegloff, 1992, pp. 1321)

01 Marty: Loes, do you have a calendar

02 Loes: Yeah ((reaches for desk calendar))

03 Marty: Do you have one that hangs on the wall?

04 Loes: Oh you want one.

05 Marty: Yeah 
Marty's turn can be understood into two ways as a pre-request to borrow a calendar or as a pre-request for having a calendar (Clift, 2014, p. 107). It seems that Loes's reaction to Marty's turn is a request to her calendar. With reference to actions made by the involved participant, Lose goes to her own desk to perform the action of request. Remarkably, Marty produces another and diverse form of request aimed to track the original turn (Liddicoat, 2007, p. 206-207).

\section{Method}

\subsection{Participants}

The participants of the study are staff members in some departments of English in Iraqi universities. They are (12) Iraqi university staff members and researchers. They are MA and $\mathrm{PhD}$ holders and MA and $\mathrm{PhD}$ researchers. This stage constitutes the target of the present study because it is considered the most advanced level at the university in Iraq. The ages of the partakers are from 26 to 50 years.

\subsection{Data}

\subsubsection{Data Recording}

The sample of data of the study is generated from naturally occurring recorded interactions of some Iraqi university staff members and researchers in viva discussions. To achieve this purpose, a total number of about 4 hours and 20 minutes of naturally occurring interactions is recorded. To achieve the purpose of recording these discussions, a special instrument is being exploited which is called "Sony UX560F Digital Voice Recorder UX Series". This device is used to record all the interactions in the academic situation. It is an ideal device because it is small and it is capable of recording all voices and sounds from all the directions of the site of the study. The implication of using this tiny and advanced voice recorder is that the quality of the data is perfect. The real names of the participants in the study are encoded as "examiner" or "researcher" in order to preserve the highest priorities of the privacy and ethical considerations of the study.

\subsubsection{Data Transcription}

Data transcription is the center upon which the study is established. Accordingly, the study adapts Gail Jefferson's (2004: 24-31 cited in Jefferson et al., 2018: xi-xii) conversational analytic system of transcription as a framework in transcribing the datasets of the study. This framework is implemented purposely because of its comprehensiveness in representing different features of talk. The stage of data transcription requires some considerations to be addressed. The audiotaped data is first recorded and then transferred to the computer to be processed for the next step, which is data transcription. Furthermore, this stage necessitates many active observations to the entire datasets of the audio tracks.

Relevant transcribed notations are provided as soon as the researcher captures an occurrence, which is of value in representing the purposes of the study. This step is important in that it allows the researcher to observe different small features of talk, which are vital finalizations of the analysis of the data like "[O:::h, uhm ,uh, pause, and repetition etc.]" (Kääntä, 2010, pp. 99-101).

It worth mentioning the fact, that there are some general conventions such as numbers $1,2,3,4, \ldots$, etc. which indicate the lines of turn-taking system. Moreover, the bold line (s) or word (s) represents that the undertaken analysis is focused on these structures. A specialized conversational analytic program called "CLAN" is utilized to manually digitize and convert the spoken language into written transcribed language. This program is one aspect of a project developed at Carnegie Mellon University (USA) by Brian MacWhinney. The transcriptions of the data are done only to the situations, which serve the purposes of the present study. The instance, like silent situations and off-topic talks, etc. are not considered. However, since the basic tool of acquiring data is a digital voice recorder, the participants' visual resources actions are not considered as well.

\subsubsection{Data Transcription Procedures and Description}

\subsubsection{Data Transcription Procedures}

Some procedures are adapted in processes of data transcription, which are as follows (Kääntä, 2010: 99-101; and Kusey, 2016: 105-107; and Martika and Sidnell, 2020: 250):

1. Converting the audiotaped tracks from the digital voice recorder to the computer and making relevant preparations such as organizing the tracks into special folders.

2. Downloading, installing, and preparing a conversational analytic transcription software package from the official website of the most specialized and prominent worldwide talk corpora (https://talkbank.org/). This 
website contains a specialized program called (CLAN) to manually digitize and encode the spoken language into written and transcribed language.

3. Converting the audio tracks from the computer into (CLAN) program and making relevant technical arrangements such as creating a special conversational analytic corpus for the transcending the audio tracks and conducting multiple, focused, and active observations to the entire dataset of audio tracks.

4. Taking into account some established considerations such as the numbers of turns, names of the participants, ethical considerations of the participants, etc.

5. Conducting transcription according to Jefferson's transcription system (2004: 24-31 cited in Jefferson et al. 2018: xi-xii).

6. Putting the dataset of the study into orthography with turn-taking.

\subsubsection{Description of Data}

\section{A. Data Description Features}

The features of the communicative situation are as follows:

\section{a. Genre}

Genre refers to the kind of speech event used. Genre may has the form of conversation, story, political debate, story, joke, lecture, poem, myth, tale, proverb, riddle, curse, prayer, oration, lecture, commercial, form letter, editorial etc. (Kiesling, 2012: 81; Flowerdew, 2014: 11; and Van Dijk (2015:1). Naturally occurring interactions are the dominant characteristics of this type of genre. As such, the genre of this study is the institutional one of academic discussion-oriented naturally occurring conversation.

\section{b. Length}

The instances of repair in the extracts of the study are different in that they vary in terms of the length of the lines as they range approximately from ( 1 line to 25 lines). The length whether it is short or long is not a crucial factor as long as the markers of repair are exploited at the right time and place to fix the troubles of talk that hinder the sense of intelligibility, progressivity, or intersubjectivity, etc. between the interactants. The datasets of the present study are of (4 hours and 20 minutes) hours of naturally occurring viva discussions.

\section{c. Form}

Talk is the main source of data in CA, which can be acquired by video or audio recordings of interactions. As such, the taped data are then reproduced in the form of a written, systematically and meticulously transcribed language to be ready for the analysis. The data of the present study are audibly recorded and then transcribed to be analyzed. It is worth noting that all the extracts of the literature review are naturally occurring conversations which are taken from different reliable sources and for that reason, they are being cited. Some extracts are modified either because of text length change or by going directly to exemplify the area in order to save room or because of the necessary change of the names of the participants for privacy. However, the slight modifications do not change any significant contents of the structure of the extracts.

\section{B. Data Context Features}

There are some related factors, which facilitate the identifications of the speech event. These adopted features are as follows (Zhu and Han, 2010: 141-142):

\section{a. The Addressor and the Addressee}

The addressor or the speaker refers to the participant who produces the speech, while the addressee is the individual (s) who receives the commutative speech signals, namely the listener (s), or the hearer (s) or the audience (Senft, 2014: 120). The examined datasets of the study show a reciprocal and distinguishable sense of these notions in that both of the addressor and addressee are in interchangeable status by initiating the repair strategy or by receiving the initiated repair occurrence. Accordingly, the two entities of the data are either the examiner or the researcher.

\section{b. The Topic}

The topic is the reciprocal self-conscious expectations of the participants' talks or thoughts, which are taken into consideration by both the listener and the speaker. The topic can be manifested in the content, type, or issues, which are being discussed in a talk (Zhu and Han, 2010: 141-142). Accordingly, the data shows that the participants are engaged in academic discussions. 


\section{c. The Settings}

The setting refers to the actualities of space and time in which the communicative situations are being produced (Pérez-Milans, 2018: 118). Therefore, the setting of the undertaken study is of academic discussion genre. These discussions take place in some of the Iraqi universities, departments of English. The time of recording the data is between 2019 .

\section{d. The Ends}

The ends refer to the goals or the purposes of which the commutative event is aiming to accomplish (Floyd, 2018: 377). Consequently, theoretically speaking, no type of talk trouble is excludable from the notion of repair (Seedhouse, 2013: 207). As such, repair in the present dataset of the study can be exploited purposely for fixing troubles of hearing, speaking, listing, understanding, etc. (Weismer and Brown, 2021: 369).

\subsection{The Model of Analysis}

A special eclectic CA model is developed to fulfill the objectives of the present study. The model is incorporated from representative theorists and writers, as follows:

\section{Dulton-Puffer (2007) and Schegloff and Sacks, (2018):}

These theories are used to analyze the trouble sources that trigger the strategies of repair.

\section{Dulton-Puffer (2007), Roshan (2014), and Schegloff and Sacks, (2018):}

These theories are used to analyze repair, non-repair, miss-repair, and repair failures.

\section{Schegloff (1992), Schegloff (1997a, 1997a,), Schegloff (2000), and Schegloff and Sacks, (2018):}

This theory is used to analyze positions of repair.

\section{Results and Discussion}

\subsection{The Trouble Sources of Repair}

The data of the study yields 342 occurrences of trouble sources. The trouble source is the incentive, which activates the repair strategy to be initiated. The following table demonstrates the frequency and percentages of the occurrences of trouble sources:

Table 1. Frequency and Percentages of the Repair Trouble Sources in the Iraqi University Viva Discussions

\begin{tabular}{llll}
\hline No & Trouble Sources & Frequencies & $\mathbf{\%}$ \\
\hline $\mathbf{1}$ & Grammar & 76 & 22.22 \\
\hline $\mathbf{2}$ & Vocabulary & 47 & 13.74 \\
\hline $\mathbf{3}$ & Pronunciation & 87 & 25.48 \\
\hline $\mathbf{4}$ & Discourse & 9 & 2.63 \\
\hline $\mathbf{5}$ & Factual information & 5 & 1.46 \\
\hline $\mathbf{6}$ & Channel & 8 & 2.33 \\
\hline $\mathbf{7}$ & Processing & 73 & 21.34 \\
\hline $\mathbf{8}$ & Misunderstanding errors & 33 & 9.64 \\
\hline $\mathbf{9}$ & Violation of social norms errors & 0 & 0.00 \\
\hline $\mathbf{1 0}$ & Repair of inaudible error & 0 & 0.00 \\
\hline $\mathbf{1 1}$ & Repair of no errors & 4 & 1.16 \\
\hline $\mathbf{1 2}$ & Imagined mistakes & 0 & 0.00 \\
\hline Total & 342 & 100 \\
\hline
\end{tabular}

The above table elucidates that the pronunciation trouble sources result in the highest occurrences in the data, 87 occurrences, $25.48 \%$. Pronunciation trouble sources are the indicators of troubles in the articulations of sounds, which slow down the normal delivery of oral interaction. This outcome indicates some deficits in the level of strategic competence. However, the participants highlight a expedite tendency towards repairing these deficiencies of oral interaction. This is related to the functionalization and socialization principles. The functionalization principle is demonstrated by performing different speech acts, such as" adopting, questioning, rejecting, defending or attacking" a specific point of view (Betti and Ghadhab, 2020, p. 35). According to this principle, the participants try to settle the disagreement of the standpoints by performing these different types of speech acts (van Eemeren 
and Grootendorst, 2004, p. 54). Likewise, the socialization principle deals with the different roles which the participants take in the discussion (Betti and Ghadhab, 2020, p. 35).

102

*RESEARCHER: So, this particular curshl culture.

The speaker in the above extract mispronounces and repairs one of the constituents in the utterances. He uses (curshl) and then repairs it to (culture).

Moreover, the data highlight that the second most frequent trouble source is that of grammar, 76 occurrences and $22.22 \%$. This type of trouble source impedes the oral interaction in that it causes some linguistics breakdowns of grammar, syntax, or morphology. Regardless of the fact that the participants show considerable rapidity in repairing such deficiencies. However, it indicates insufficiencies of the level of linguistic competence of the interlocutors.

173

*RESEARCHER: It could be looked up loo- looked at or and analyzed accordingly.

The above extract clarifies the talker capability to repair the inaccurate selection of the grammatical structures.

However, the data elucidates that factual information and repair of no errors are the least frequent trouble sources: $5,1.46 \% ; 4,1.16 \%$ respectively which clarify that the participants show less concerns in searching for repairing the names of certain individuals because they are much more engaged in discussing concepts and notions:

15

*RESEARCHER: For example, Foucault I used like three or four books of th-the the this author, so I had to add the date to $(\mathbf{0 . 1})$ the::: according to MLA, I have to add the date with whinnn th- th- the text.

\section{(Factual information)}

\section{1}

*EXAMINER: What is the purpose of Hanger Hame- Hunger Game, the protagonist Katniss yes Katniss, what is the purpose. (Repair of no errors)

However, the data explicates that none of the participants commits the trouble sources of the types of violation of social norms errors, repair of inaudible error, and imagined mistakes which can be attributed to the scarce violation of social norms errors because the participants are in socially repressed institutional setting. In an earlier study by Betti and Hasan (2020: 56), it is concluded that "the MA candidates use SAs [speech acts] which belong to the SA categories: representatives, directives and expressives ...), whereas the Ph.D. candidates, in comparison, make use of SAs which belong to: representatives, directives, commissives and expressives ... though the Ph.D. candidates issue three commissive SAs. This is an indication that both of the MA and Ph.D., on the one hand, have much more concentration on the aim of convincing the committee than on future commitment and, on the other hand, they are not in [a] position to issue declarations". Moreover, they are carefully prepared to discuss the piece of work under examination, which weakens the imagined mistakes to be activated. In other words, imagined errors are not available since it they are prepared for such oral examination. As a result, the analysis of the trouble sources refutes hypothesis (1) which states that (misunderstanding errors is the most frequent repair trouble source in the Iraqi university viva discussions in English) and accepts the alternative hypothesis which states that (pronunciation trouble source is the most frequent repair trouble source in the Iraqi university viva discussions in English).

\subsection{Repair Inadequacy Patterns}

Repair inadequacy is a status upon which the organization of repair is insufficient to meet the interactional competencies of the speakers who discover their inauspiciousness confinement to repair the troubles of talk:

Table 2. Frequency and Percentages of Repair Inadequacy in the Iraqi University Viva Discussions in English

\begin{tabular}{llll}
\hline $\mathbf{N}$ & Repair adequacy & Frequency & $\mathbf{\%}$ \\
\hline $\mathbf{1}$ & Non-repair & 20 & 5.52 \\
$\mathbf{2}$ & Miss-repair & 0 & 0.00 \\
\hline $\mathbf{3}$ & Self-initiated repair failure & 0 & 0.00 \\
\hline $\mathbf{4}$ & Other-initiated repair failure & 0 & 0.00 \\
\hline Total & 20 & 100 \\
\hline
\end{tabular}


The above table explicates that non-repair, which is the abandonment of repairing the trouble source, results in 20 occurrences, $5.52 \%$. This illustrates that there is a slight deficit in the level of the competence of the speakers, something which demonstrates that the institutional setting restrains the participants to take decisive action of repairing the trouble since they are equipped with many inquiries in a limited time. Additionally, it reveals that the interactional atmosphere of the situation deprives the speakers from going backward to repair the troubles of the previously articulated talk. The following extract demonstrates that the speaker takes no action of repairing the mispronunciation of the word (study).

\section{1}

*EXAMINER.. He is from department of education; his field of study $((/ \mathrm{ssdty} /))$ is literature.

However, hypothesis (2) which states that (non-repair is the most frequent repair inadequacy in the discussions) is accepted.

For the sake of comparison, the following table presents the frequency and percentages of repairs and non-repairs.

Table 3. The Frequency and Percentages of Repairs and Non-Repairs in the Discussions

\begin{tabular}{llll}
\hline $\mathrm{N}$ & Repair adequacy & Frequency & $\%$ \\
\hline 1 & Repair & 342 & 94.48 \\
\hline 2 & Non-repair & 20 & 5.52 \\
Total & & 362 & 100 \\
\hline
\end{tabular}

The above table clarifies that repair cases are divided into $342,94.48 \%$ valid cases of repair and 20 case of nonrepair, and $5.52 \%$. The highest frequency of occurrences by repair indicates that the participants are dexterous enough to initiate repair and to manage language oral troubles submissively and meritoriously and that they are competently maneuvering the use of repair to eradicate the interactive difficulties. Moreover, this designates that the participants are capable of managing their own competence deficits that hinder the progressivity of the oral interaction. As result of the analysis of repair inadequacy patterns hypothesis (3) which states that (repair is more frequent than none-repair in the data) is accepted.

However, the data exposes that the rest of repair inadequacy results in (zero) occurrences, i.e. , miss-repair and self-repair and other-repair. Such frequencies confirm the considerable competencies of the speakers in managing interactive situations in that they are capable of repairing without failures. In other words, the participants in the viva discussions are proficient enough to produce repair and to operate such inadequate troubles of the talk. This finding is supported by Betti and Yaseen (2020: 56): "The reasons ... could be due to the subjects' little practice of using the FL pragmatic rules and could be the impact of the first language".

\subsection{Positions of Repair}

The 342 occurrences of repair are distributed to same-turn, transition-space, third-turn, third-position, second position, and fourth positions:

Table 4. Frequency and Percentages of Repair Positions in the Iraqi University Viva Discussions

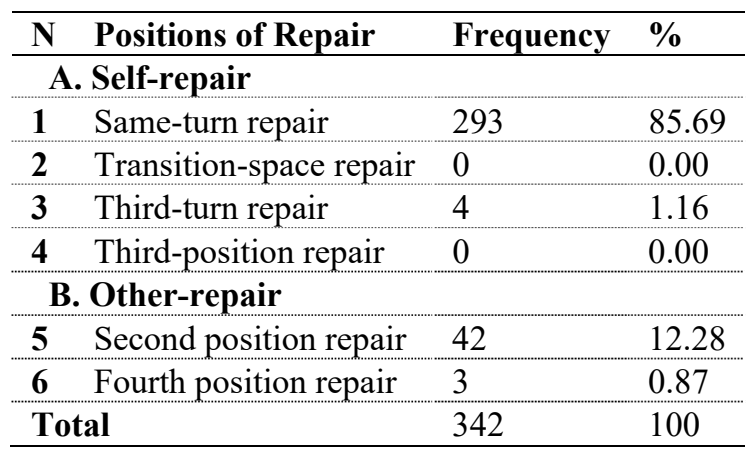

The above table illustrates that same turn repair position is the highest frequency of 293 occurrences, and $85.69 \%$. This implies that the participants in the discussions debates tend to repair in the same turn of the trouble source, and that this near position of repair to the trouble source is an indicator of the high competencies of the speakers. 
Moreover, this position exploits many self-repair operations, which demonstrates its diverse, functionalities in dealing with oral troubles:

33

*RESEARCHER: I put like one sentence explain howww what hhhh what am I going to discuss.

The above extract illustrates that the speaker is repairing the utterance in the same turn.

Additionally, it appears that the second most frequent position is devoted to the other repair trajectory and its second position repair, 42 occurrences, $12.28 \%$. This indicates that the speakers are encountering some troubles, which designate the second turn as being problematical. As such, repair can be initiated in the third turn and completed in the third one. For that reason, many formats can be used in this position such as open class repairs, candidate understandings, and repetitions, etc.:

\section{6}

*EXAMINER: You say for example labeling improves the performance of power but do not you believe that an implicit criticism of power in the way it was applied ok on people in the treo- trilogy .

*RESEARCHER: hhhh what do you mean criticism, by (who/whom)?

*EXAMINER: Now, is Ruth criticize power or is she hhh praising it?

*RESEARCHER: well ok I see she is not taking a side.

*EXAMINER: Not taking a side, that is it.

The above extract presents the second position repair in which a trouble is located in the first turn and repair is initiated in the second turn thus it is completed in the third turn.

However, the data reveals the rarity of some position such as transition-space repair and third-position repair. The above positions of repair results in zero. Transition space position of repair is the one, which is generated at the first potential completion of the turn. For that reason, the proficient speakers of the data of the study tend not to prolong too much for remote positions and wait for such a position too much in that they tend to initiate repair in closer position than this, which is the same turn position. Similarly, the third position repair is exploited to facilitate the complexities of massage comprehensibility. As such, the data reveals that the speakers exert remarkable efforts in order to deliver highly unblemished and informative knowledge since they are controlled by a context, which obligates them to act accordingly. For that reason, the low frequency of this position is attributed to the alertness of speakers to the plausible sources of incomprehensibility.

As a result of the analysis of positions of repair, hypothesis (4) which states that, (the fourth position of repair is the most frequent position of repair in the data) is refuted, and an alternative hypothesis which states that (same turn position of repair is the most frequent position of repair in the data) is accepted.

\section{Conclusions}

The following conclusions are arrived at as a result of the theoretical and the practical sides of the study:

1. The eclectic model of the study gives a multi- faceted description of all the trouble sources of repair, and repair inadequacy patterns, and positions. Then, according to the study, this model is a comprehensive one. The study shows the applicability and workability of the developed model for analyzing the previously mentioned areas of repair in the Iraqi university viva discussions.

2. It is found that repair sources of trouble include grammar, vocabulary, pronunciation, discourse, factual information, channel, processing, misunderstanding errors, repair of no errors.

3. Pronunciation trouble source of repair results in the highest occurrences of the data. This outcome indicates some deficits in the level of strategic competence in pronunciation.

4. Factual information and repair of no errors are the least repair frequent trouble sources.

5. None of the participants commit the trouble sources of the types of violation of social norms errors, repair of inaudible error, and imagined mistakes.

6. The data shows a prevailing tendency toward initiating valid repair cases other than non-repair cases.

7. The study reveals that non-repair is the most frequent repair inadequacy in the discussions.

8. The data exposes that there are (zero) occurrence of miss-repair, self-repair and other-repair failures. For that reason, the comprehensive inventory of repair prevents the inadequacies of taking place in the situation in that a wide variety is available to be initiated. 
9. Same turn repair position is the most frequent while fourth position repair is least frequent one.

10. The data shows that the second most frequent trouble source is that of grammar, which impedes the oral interaction in that it causes some linguistics breakdowns of grammar, syntax, or morphology. However, it indicates the insufficiencies of the level of linguistic competence of the interlocutors.

\section{Acknowledgements}

I would like to acknowledge my indebtedness to my wife Prof. Zainab Kadim Igaab for reading an earlier version of this paper.

\section{References}

Al-Seady, Mohammed J. B. Betti (2002). Some Morphological, Lexical and Syntactic Aspects of the Interlanguage of Third Year Students/Dept. of English/College of Education/ University of Qadisiya. Journal of Qadisiya for Educational Sciences, 2(1), 13-19.

Alzaidi, H. O. (2016). The Practices of Multiple Other-Initiated Repair in Online Second Language Interaction. Unpublished Doctoral Dissertation. Newcastle upon Tyne: Newcastle University.

Arundale, R. B. (2020). Communicating \& Relating: Constituting Face in Everyday Interacting. Oxford: Oxford University Press. https://doi.org/10.1093/oso/9780190210199.001.0001

Bazerman, C. (2012). "Genre as Social Action". In Gee, J. P., \& Handford, M (Eds.). The Routledge Handbook of Discourse Analysis (pp. 226-238). London; New York: Routledge.

Benjamin, T., \& Drew. P, (n.d.). (2018). "Jefferson's "Wild side" of Conversation analysis" In Jefferson G. Repairing the broken surface of talk: Managing problems in speaking, hearing, and understanding in conversation (pp. 1-26). New York: Oxford University Press.

Betti, M. J. (2007). Jokes in Iraq: A Study of Coherence and Cohesion. Journal of the College of EducationUniversity of Wasit, 1(1), 399-411. https://doi.org/10.31185/eduj.Vol1.Iss1.694

Betti, M. J., \& Al-Juboury, C. F. (2015). Approaches and Methods of Teaching English as a Foreign Language. Diwaniya: Nippur Publishing.

Betti, M. J., \& Hashim, T. G. (2018). The Lawyer's Discourse in the Courtroom: A Contrastive Study in English and Arabic. International Journal of Linguistics, 8(3), 276-296. https://doi.org/10.5539/ijel.v8n3p276

Betti, M. J., \& Ghadhab, A. O. (2020). A Pragma-Dialectical Study of the argumentative Indicators in American Electoral Campaign Debates. International Journal of Advancement in Social Science and Humanity, 9, 2774.

Betti, M. J., \& Yaseen, K. S. (2020). The Iraqi EFL Learners' Use of Conversational Maxims at the University Level. Education, Language and Sociology Research, 1(1), 43-60. https://doi.org/10.22158/elsr.v1n1p43

Betti, M. J., \& Hasan, A. A. (2020). The Iraqi EFL Learners' Ability to Use Speech Acts in MA and Ph.D. Theses Defense. Education, Language and Sociology Research, 2(2), 1-23. https://doi.org/10.22158/elsr.v1n2p41

Bloor, M., \& Wood, F. (2006). Keywords in Qualitative Methods: A Vocabulary of Research Concepts. London: Sage Publications. https://doi.org/10.4135/9781849209403

Burford-Rice, R., \& Augoustinos, M. (2017). "I Didn't Mean That: It was Just a Slip of the Tongue: Racial Slips and Gaffes in the Public Arena". British Journal of Social Psychology, 57(1), 21-42. https://doi.org/10.1111/bjso.12211

Candlin, C., Crichton, J., \& Moore, S. H. (2017). Exploring Discourse in Context and in Action. London: Palgrave MacMillan. https://doi.org/10.1057/978-1-137-31506-9

Carterette, E. C., \& Jones, M. H. (1974). Informal Speech: Alphabetic \& Phonemic Texts with Statistical Analyses and Tables. Berkeley: University of California Press. https://doi.org/10.1525/9780520329331

Cho, E. H. (2008). An Examination of the Use of Repair Strategies of Elementary English as a Second Language (ESL) Students by Class Types and Grade Levels. Unpublished Doctoral Dissertation. Texas: Texas A\&M University.

Cho, E. H., \& Larke, P. J. (2010). "Repair Strategies Usage of Primary Elementary ESL Students: Implications for ESL Teachers". TESL-EJ, 14(3), (pp. 1-18).

Clayman, S. E., \& Gill, V. T. (2012). “Conversation Analysis”. In Gee, J. P., \& Handford, M. (Eds.). The Routledge Handbook of Discourse Analysis (pp. 120-134). New York: Routledge. 
Clift, R., Drew, P., \& Hutchby, I. (2009). “Conversation Analysis” In D’hondt, S., Östman, J. O., \& Verschueren, J. (Eds.). Handbook of Pragmatics (pp. 40-54). Amsterdam: John Benjamins Pub. Co. https://doi.org/10.1075/hoph.4.02cli

Cohen, A. D. (2012). "Comprehensible Pragmatics: Where Input and Output Come Together”. In M. Pawlak (Ed.), New Perspectives on Individual Differences in Language Learning and Teaching (pp. 249-261). Berlin: Springer Berlin Heidelberg. https://doi.org/10.1016/j.pragma.2011.12.006

Couper-Kuhlen, E., \& Selting, M. (2018). Interactional Linguistics (1st ed.). Cambridge: Cambridge University Press. https://doi.org/10.1017/9781139507318

Curl, T. S. (2006). "Offers of Assistance: Constraints on Syntactic Design”. Journal of Pragmatics, 38(8), 12571280. https://doi.org/10.1016/j.pragma.2005.09.004

Curl, T. S., \& Drew, P. (2008). "Contingency and Action: A Comparison of Two Forms of Requesting”. Research on Language and Social Interaction, 41(2), 129-153. https://doi.org/10.1080/08351810802028613

Dalton-Puffer, C. (2007). Discourse in Content and Language Integrated Learning (CLIL) Classrooms. Philadelphia: John Benjamins. https://doi.org/10.1075/11lt.20

Drew, P. (1997). “'Open'class Repair Initiators in Response to Sequential Sources of Troubles in Conversation”. Journal of Pragmatics, 28(1), 69-101. https://doi.org/10.1016/S0378-2166(97)89759-7

Egbert, M. (1998). "Miscommunication in Language Proficiency Interviews of First-Year German Students: A Comparison with Natural Conversation". In Young, R., \& He, A. W. (Eds.). Talking and Testing. Discourse Approaches to the Assessment of Oral Proficiency (pp. 147-172). Amsterdam: John Benjamins Publishing Company. https://doi.org/10.1075/sibil.14.10egb

Ekberg, S. (2012). "Addressing a Source of Trouble Outside of the Repair Space”. Journal of Pragmatics, 44(4), 374-386. https://doi.org/10.1016/j.pragma.2012.01.006

Enfield, N. J., \& Stivers, T. (Eds.). (2007). Person Reference in Interaction: Linguistic, Cultural, and Social Perspectives. Cambridge: Cambridge University Press. https://doi.org/10.1017/CBO9780511486746

Enfield, N. J., Stivers, T., \& Sidnell, J. (2014). "Language Presupposes an Enchronic Infrastructure for Social Interaction”. In Dor, D., Knight, C., \& Lewis, J. (Eds.). The Social Origins of Language (pp. 92-104). Oxford: Oxford University Press. https://doi.org/10.1093/acprof:oso/9780199665327.003.0008

Engfer, H. (2011). "Cake or Meat? A Case Study on Dinner Conversations in a Migrant-in-the-Family Household in Germany". In Backhaus, P. (Ed.). Communication in Elderly Care: Cross-Cultural Perspectives (pp. 112 128). London: Continuum.

Fletner, E. M. (2016). The Use of Gesture in Self-Initiated Self-Repair Sequences by Persons with Non-Fluent Aphasia. Unpublished MA thesis, Lexington, University of Kentucky.

Flowerdew, J. (2012). Discourse in English Language Education. Abingdon: Routledge. https://doi.org/10.4324/9780203080870

Fox, B. A., \& Jasperson, R. (1995). "A syntactic exploration of repair in English conversation. Alternative Linguistics: Descriptive and Theoretical Modes". In Davis, P. W. (Ed.). Alternative Linguistics: Descriptive and Theoretical Modes (Vol. 102) (pp. 77-134). John Benjamins Publishing. https://doi.org/10.1075/cilt.102.04fox

Frankel, F., \& Wood, J. J. (2012). Social Skills Success for Students with Autism/Asperger's: Helping Adolescents on the Spectrum to Fit in (1st ed). San Francisco: Jossey-Bass.

Garcia, A. C. (2013). An Introduction to Interaction: Understanding Talk in Formal and Informal Settings. New York: Bloomsbury.

Gilbert, J. B. (2008). Teaching Pronunciation Using the Prosody Pyramid. Cambridge: Cambridge University Press.

Haakana, M., \& Kurhila, S. (2009). "Other-Correction in Everyday Interaction: Some Comparative Aspects. In Haakana, M., Laakso, M., \& Lindström, J. (Eds.). Talk in Interaction: Comparative Dimensions (pp. 152179). Helsinki: Finnish Literature Society/SKS. https://doi.org/10.21435/sflin.14

Have, P. T. (2007). Doing Conversation Analysis (2nd ed). Los Angeles: Sage. https://doi.org/10.4135/9781849208895

Hayashi, M., Raymond, G., \& Sidnell, J. (Eds.). (2013). Conversational Repair and Human Understanding. 
Cambridge: Cambridge University Press. https://doi.org/10.1017/CBO9780511757464

Heinemann, T., \& Steensig, J. (2018). “Justifying Departures from Progressivity: The Danish Turn-Initial Particle Altsåden Danske Tur-Initiale Partikel Altså”. In Heritage, J., \& Sorjonen, M. L. (Eds.). Between Turn and Sequence Turn-initial particles across languages (pp. 445-474). John Benjamins Publishing Company. https://doi.org/10.1075/slsi.31.15hei

Heinemann, T., Steensig, J., \& Eskildsen, S. W., Pekarek Doehler, S., \& Piirainen-Marsh, A. (2019). Conversation Analytic Research on Learning-in-Action: The Complex Ecology of Second Language Interaction "in the wild.". Cham: Springer Nature.

Heritage, J. (2002). "The Limits of Questioning: Negative Interrogatives and Hostile Question Content". Journal of Pragmatics, 34(10-11), 1427-1446. https://doi.org/10.1016/S0378-2166(02)00072-3

Hoey, E. M. \& Kendrick, K. H. (2018). "Conversation Analysis", In Groot, A. M. B. de, \& Hagoort, P. (Eds.). Research Methods in Psycholinguistics and the Neurobiology of Language: A Practical Guide (pp. 151-173). Hoboken, NJ: John Wiley \& Sons Inc.

Hutchby, I., \& Wooffitt, R. (2002). Conversation Analysis: Principles, Practices, and Applications. Malden: Polity Press.

Hutchby, I., \& Wooffitt, R. (2008). Conversation Analysis (2nd ed). Malden: Polity Press.

Hutchby, I., \& Wooffitt, R. (2021). "Conversation Analysis". In Atkinson, P. A., Delamont, S., Williams, R. A., Cernat, A., \& Sakshaug, J. (Eds.). Sage Research Methods Foundations (pp.1-21). London: Sage Publications.

Iwai, Y. (2011). "The Effects of Metacognitive Reading Strategies: Pedagogical Implications for EFL/ESL Teachers". The Reading Matrix, 11(2), (pp.150-159).

Jefferson, G. (1974). "Error Correction as an Interactional Resource". Language in Society, (2). 181-199. https://doi.org/10.1017/S0047404500004334

Jefferson, G. (1987). “On Exposed and Embedded Corrections". In Button, G., \& Lee, J. R. (Eds.).Talk and Social Organization (pp.86-100). Clevedon: Multilingual Matters.

Jefferson, G. (2004). "Glossary of Transcript Symbols with an Introduction". In Lerner, G. H. (Ed.). Conversation Analysis: Studies from the First Generation (13-34). Amsterdam: John Benjamins Publishing Company. https://doi.org/10.1075/pbns.125.02jef

Jefferson, G. (2007). "Preliminary Notes on Abdicated Other-Correction". Journal of Pragmatics, 39(3), 445-461. https://doi.org/10.1016/j.pragma.2006.07.006

Jefferson, G. (2018). Repairing the Broken Surface of Talk: Managing Problems in Speaking, Hearing, and Understanding in Conversation (J. Bergmann \& P. Drew, Eds.). New York: Oxford University Press.

Kääntä, L. (2010). Teacher Turn-Allocation and Repair Practices in Classroom Interaction. Unpublished doctoral dissertation. Jyväskylä, Finland ,University of Jyväskylä.

Kendrick, K. H. (2015a). "The Intersection of Turn-Taking and Repair: the Timing of Other-Initiations of Repair in Conversation”. In Holler, J., Casillas, M., H Kendrick, K., \& C Levinson, S. (2015) (Eds.). Turn-Taking in Human Communicative Interaction (pp. 146-161). Lausanne: Frontiers Media SA. https://doi.org/10.3389/fpsyg.2015.00250

Kendrick, K. H. (2015a). "Other-Initiated Repair in English". Open Linguistics, (1), 164-190. https://doi.org/10.2478/opli-2014-0009

Kendrick, K. H. (2019). "Evidential Vindication in Next Turn”. In Speed, L. J., O'Meara, C., San Roque, L., \& Majid, A. (Eds.). Perception Metaphors (pp. 253-274). Amsterdam: John Benjamins Publishing Company. https://doi.org/10.1075/celcr.19.13ken

Kiesling, S. F. (2012). "Ethnography of Speaking”. In Paulston, C. B., Kiesling, S. F., \& Rangel, E. S. (Eds.). The Handbook of Intercultural Discourse and Communication (pp. 77-89). Chichester: John Wiley \& Sons, Ltd. https://doi.org/10.1002/9781118247273.ch5

Kim, M. S., \& Kim, S. H. (2014). "Initiating Repair with and Without Particles: Alternative Formats of OtherInitiation of Repair in Korean Conversation". Research on Language and Social Interaction, 47(4), 331-352. https://doi.org/10.1080/08351813.2014.958277

Kim, S. H., \& Park, I. (2015). “Test Taker-Initiated Repairs in an English Oral Proficiency Exam for International Teaching Assistants”. Text \& Talk, 35(2), 237-262. https://doi.org/10.1515/text-2014-0036 
Kitzinger, C. (2008). "Developing Feminist Conversation Analysis: A Response to Wowk". Human Studies, 31(2), 179-208. https://doi.org/10.1007/s10746-008-9088-7

Ko, S. (2013). Understanding the Dynamics of Classroom Communication. Newcastle upon Tyne: Cambridge Scholars Publishing.

Kormos, J. (2000a). "The Timing of Self-Repairs in Second Language Speech Production”. Studies in Second Language Acquisition, 22(2), 145-167. https://doi.org/10.1017/S0272263100002011

Kormos, J. (2000b). "The Role of Attention in Monitoring Second Language Speech Production”. Language Learning, 50(2), 343-384. https://doi.org/10.1111/0023-8333.00120

Kusey, C. L. (2016). Same-Turn Self-Repair Practices in Peer-Peer L2 Conversational Dyads. Unpublished Doctoral dissertation, Austin: University of Texas.

Laakso, M., \& Sorjonen, M. L. (2010). "Cut-Off or Particle—Devices for Initiating Self-Repair in Conversation". Journal of Pragmatics, 42(4), 1151-1172. https://doi.org/10.1016/j.pragma.2009.09.004

Land, V., \& Kitzinger, C. (2007). "Some Uses of Third-Person Reference Forms in Speaker Self-Reference". Discourse Studies, 9(4), 493-525. https://doi.org/10.1177/1461445607079164

Lee, S., Dinis, M. C. D. S. N., Lowe, L., \& Anders, K. (2016). Statistics for International Social Work and Other Behavioral Sciences (1st ed.). Oxford: Oxford University Press.

Lerner, G. H. (2004). "On The Place of Linguistic Resources in the Organization of Talk-In-Interaction: Grammar as Action in Prompting a Speaker to Elaborate". Research on Language and Social Interaction, 37(2), 151184. https://doi.org/10.1207/s15327973rlsi3702_3

Lerner, G. H. (Ed.). (2004). Conversation Analysis: Studies from the First Generation. Amsterdam: John Benjamins Publishing Company. https://doi.org/10.1075/pbns.125

Lerner, G. H., \& Kitzinger, C. (2007). "Extraction and Aggregation in the Repair of Individual and Collective SelfReference". Discourse Studies, 9(4), 526-557. https://doi.org/10.1177/1461445607079165

Lerner, G. H., \& Bolden, G. B., Hepburn, A., \& Mandelbaum, J. (2012). "Reference Recalibration Repairs: Adjusting the Precision of Formulations for the Task at Hand". Research on Language \& Social Interaction, 45(2), 191-212. https://doi.org/10.1080/08351813.2012.674190

Levinson, S. C. (2008). Pragmatics. Cambridge: Cambridge University Press.

Li, L. (2020). Language Teacher Cognition: A Sociocultural Perspective. Palgrave Macmillan, London. https://doi.org/10.1057/978-1-137-51134-8

Liddicoat, A. (2007). An Introduction to Conversation Analysis. London; Continuum.

Liddicoat, A. (2011). An Introduction to Conversation Analysis. London; Continuum.

Liebscher, G., \& Dailey-O'Cain, J. (2003). "Conversational Repair as a Role-Defining Mechanism in Classroom Interaction”. The Modern Language Journal, 87(3), 375-390. https://doi.org/10.1111/1540-4781.00196

Lilja, N. (2014). "Partial Repetitions as Other-Initiations of Repair in Second Language Talk: Re-Establishing Understanding and Doing Learning". Journal of Pragmatics, 71, 98-116. https://doi.org/10.1016/j.pragma.2014.07.011

Markee, N. (2009). Conversation Analysis. New Jersey: Routledge.

Markee, N. (Ed.). (2015). The Handbook of Classroom Discourse and Interaction. Chichester: John Wiley \& Sons. https://doi.org/10.1002/9781118531242

McTear, M., Callejas, Z., \& Griol, D. (2016). The Conversational Interface: Talking to Smart Devices (1st ed. 2016). Cham: Springer International Publishing : Springer. https://doi.org/10.1007/978-3-319-32967-3

Moore, R. J., \& Arar, R. (2019). Conversational UX Design: A Practitioner's Guide to the Natural Conversation Framework. New York: Association for Computing Machinery. https://doi.org/10.1145/3304087.3304092

Nassaji, H. (2015). The Interactional Feedback Dimension in Instructed Second Language Learning: Linking Theory, Research, and Practice. New York: Bloomsbury Academic, An imprint of Bloomsbury Publishing Plc.

Nathan, M. J., \& Alibali, M. W. (2011). How Gesture Use Enables Intersubjectivity in the Classroom. In G. Stam \& M. Ishino (Eds.), Gesture Studies (Vol. 4, pp. 257-266). Amsterdam: John Benjamins Publishing Company. $\mathrm{https} / / / \mathrm{doi} .0 \mathrm{rg} / 10.1075 / \mathrm{gs} .4 .23$ nat 
Pachler, N., \& Field, K. (2001). Learning to Teach Modern Foreign Languages in the Secondary School: A companion to School Experience. London; New York: Routledge. https://doi.org/10.4324/9780203181928

Pachler, N., Evans, M., Redondo, A., \& Fisher, L. (2014). Learning to Teach Foreign Languages in the Secondary School: A Companion to School Experience. Abingdon: Routledge.

Paltridge, B. (2012). Discourse Analysis: An Introduction (2nd ed). New York: Continuum.

Park, I., \& Kline, J. (2020). "Incomplete Utterances as Critical Assessments". Discourse Studies, 22(4), 441-459. https://doi.org/10.1177/1461445620914669

Pasfield-Neofitou, S. E. (2012). Online Communication in a Second Language: Social Interaction, Language Use, and Learning Japanese. Bristol: Multilingual Matters. https://doi.org/10.21832/9781847698261

Paulston, C. B., Kiesling, S. F., \& Rangel, E. S. (Eds.). (2012). The Handbook of Intercultural Discourse and Communication. Chichester: John Wiley \& Sons, Ltd. https://doi.org/10.1002/9781118247273

Pérez-Milans, M. (2018). "Metapragmatics in the Ethnography of Language policy". In Tollefson, J. W., \& PérezMilans, M. (Eds.). The Oxford Handbook of Language Policy and Planning (pp113-139). Oxford: Oxford University Press. https://doi.org/10.1093/oxfordhb/9780190458898.013.7

Person, R. F. (2016). From Conversation to Oral Tradition: A Simplest Systematics for Oral Traditions. New York: Routledge. https://doi.org/10.4324/9781315657264

Rapley, M. (2011). "Ethnomethodology/Conversation Analysis". In Harper, D., \& Thompson, A. R. (Eds.). Qualitative Research Methods in Mental Health and Psychotherapy (pp.177-192). Chichester : John Wiley \& Sons. https://doi.org/10.1002/9781119973249.ch13

Rehg, K. L., \& Campbell, L. (Eds.). (2018). The Oxford Handbook of Endangered Languages. Oxford: Oxford University Press. https://doi.org/10.1093/oxfordhb/9780190610029.001.0001

Renkema, J., \& Schubert, C. (2018). Introduction to Discourse Studies (New edition). Amsterdam; Philadelphia: John Benjamins Publishing Company. https://doi.org/10.1075/z.219

Robles, J. S. (2017). "Misunderstanding as a Resource in Interaction". Pragmatics Journal, 27(1), 57-86. https://doi.org/10.1075/prag.27.1.03rob

Romero Trillo, J. (Ed.). (2016). Global Implications for Society and Education in the Networked Age. Switzerland: Springer. https://doi.org/10.1007/978-3-319-41733-2_1

Roshan, G. (2014). A Study on the Categories and Strategies of Self-repair in Iranian EFL Teachers' Speech and Their Relationship with Teachers 'Major and Level of Teaching Experience. Unpublished MA Thesis. Tehran: Allameh Tabataba i University.

Schegloff, E. A., Jefferson, G., \& Sacks, H. (1977). "The Preference for Self-Correction in the Organization of Repair in Conversation". Language, 53(2), 361-382. https://doi.org/10.2307/413107

Schegloff, E. A., Jefferson, G., \& Sacks, H. (1979). The Relevance of Repair to Syntax-For-Conversation. In Givon, T. (Ed.). Discourse and Syntax (pp. 261-286). Leiden: Brill. https://doi.org/10.1163/9789004368897_012

Schegloff, E. A., Jefferson, G., \& Sacks, H. (1987a). "Some Sources of Misunderstanding in Talk-InInteraction”. Linguistics, 25(1), 201-218. https://doi.org/10.1515/ling.1987.25.1.201

Schegloff, E. A., Jefferson, G., \& Sacks, H. (1987b). "Analyzing Single Episodes of Interaction: An Exercise in Conversation Analysis". Social Psychology Quarterly, 50(2), 101-114. https://doi.org/10.2307/2786745

Schegloff, E. A., Jefferson, G., \& Sacks, H. (1987c). "Recycled Turn Beginnings: A Precise Repair Mechanism in Conversation's Turn-Taking Organization”. In Button, G., \& Lee, J. R. (Eds.). Talk and Social Organization, (pp. 70-85). Clevedon: Multilingual Matters.

Schegloff, E. A., Jefferson, G., \& Sacks, H. (1992). "Repair after Next Turn: The Last Structurally Provided Defense of Intersubjectivity in Conversation". American journal of sociology, 97(5), 1295-1345. https://doi.org/10.1086/229903

Schegloff, E. A., Jefferson, G., \& Sacks, H. (1996). "Some Practices for Referring to Persons in Talk-In-Interaction: A Partial Sketch of a Systematics". In Fox, B. A. (Ed.). Studies in Anaphora (pp. 437-486). Amsterdam : John Benjamins Publishing Company. https://doi.org/10.1075/tsl.33.14sch

Schegloff, E. A., Jefferson, G., \& Sacks, H. (1997a). "Practices and Actions: Boundary Cases of Other-Initiated Repair”. Discourse Processes, 23(3), 499-545. https://doi.org/10.1080/01638539709545001 
Schegloff, E. A., Jefferson, G., \& Sacks, H. (1997b). “Third Turn Repair”. In Guy, G. R., Feagin, C., Schiffrin, D., \& Baugh, J. (Eds.) Towards A Social Science of Language: Papers in Honor of William Labov. Volume 2: Social Interaction and Discourse Structures (pp. 31-40). Amsterdam: John Benjamins Publishing.

Schegloff, E. A., Jefferson, G., \& Sacks, H. (2000). “When 'others' Initiate Repair”. Applied linguistics, 21(2), 205243. https://doi.org/10.1093/applin/21.2.205

Schegloff, E. A., Jefferson, G., Sacks, H., \& Jefferson, G. \& Sacks, H. (2003). “The Preference for Self-correction in the Organization of Repair in Conversation". In Kasher, A. (Ed.). Pragmatics: Critical Concepts Volume VI Communication, Interaction, and Discourse (pp. 243-272). London: Routledge.

Schegloff, E. A., Jefferson, G., \& Sacks, H. (2007a). "Categories in Action: Person-Reference and Membership Categorization”. Discourse Studies, 9(4), 433-461. https://doi.org/10.1177/1461445607079162

Schegloff, E. A., Jefferson, G., \& Sacks, H. (2007b). Sequence Organization in Interaction: A Primer in Conversation Analysis I (Vol. 1). Cambridge : Cambridge university press.

Schegloff, E. A., Jefferson, G., \& Sacks, H. (2010). "Some Other uh (m) s". Discourse Processes, 47(2), 130-174. https://doi.org/10.1080/01638530903223380

Schegloff, E. A., Jefferson, G., \& Sacks, H. (2013). “Ten Operations In Self-Initiated, Same-Turn Repair”. In Hayashi, M., Raymond, G., \& Sidnell, J. (Eds.). Conversational Repair and Human Understanding (pp. 4170). Cambridge: Cambridge University Press. https://doi.org/10.1017/CBO9780511757464.002

Schegloff, E. A., Jefferson, G., \& Sacks, H., Raymond, G., Lerner, G. H., \& Heritage, J. (Eds.). (2017). Enabling Human Conduct: Studies of Talk-In-Interaction in Honor of Emanuel A. Schegloff. Amsterdam: John Benjamins Publishing Company. https://doi.org/10.1075/pbns.273.18sch

Schegloff, E. A., Jefferson, G., \& Sacks, H., \& Sacks. H, (2018). "The Preference for Self-Correction in the Organization of Repair in Conversation" In Jefferson Gail, Repairing the Broken Surface of Talk: Managing Problems in Speaking, Hearing, and Understanding in Conversation (pp. 93-126). New York: Oxford University Press.

Seargeant, P. (2009). The Idea of English in Japan: Ideology and the Evolution of a Global Language. New York: Multilingual Matters. https://doi.org/10.21832/9781847692030

Seedhouse, P. (2004). The Interactional Architecture of the Language Classroom: A Conversation Analysis Perspective. Language Learning. Hoboken: Wiley-Blackwell.

Seedhouse, P. (2013). Conversation Analysis. In Bayley, R., Cameron, R., \& Lucas, C. (Eds.). The Oxford Handbook of Sociolinguistics (91-111). Oxford: Oxford University Press. https://doi.org/10.1093/oxfordhb/9780199744084.013.0005

Senft, G. (2014). Understanding Pragmatics. Abingdon: Routledge. https://doi.org/10.4324/9780203776476

Seo, M. S., \& Koshik, I. (2010). "A Conversation Analytic Study of Gestures that Engender Repair in ESL Conversational Tutoring". Journal of Pragmatics, 42(8), 2219-2239. https://doi.org/10.1016/j.pragma.2010.01.021

Seong, G. (2006). "Choices They Make: How ESL Teachers Initiate Repair in the Classroom". English Teaching, 61(1), 227-255.

Sert, O. (2015). Social Interaction and L2 Classroom Discourse. Edinburgh: Edinburgh University Press.

Shintani, N. (2016). Input-Based Tasks in Foreign Language Instruction for Young Learners. Philadelphia: John Benjamins Publishing Company. https://doi.org/10.1075/tblt.9

Sidnell, J. (2007). "Repairing Person Reference in a Small Caribbean Community". In Enfield, N. J., \& Stivers, T. (Eds.). Person Reference in Interaction: Linguistic, Cultural, and Social Perspectives (pp. 281- 308). Cambridge: Cambridge University Press.

Smit, U. (2010). English as a Lingua Franca in Higher Education a Longitudinal Study of Classroom Discourse. Berlin: Mouton de Gruyter. https://doi.org/10.1515/9783110215519

Tateyama, Y. (2012). "Repair in Japanese Request Sequences During Student-Teacher Interactions”. In Alcón Soler, E., \& Safont Jordà, P. (Eds.). Discourse and Language Learning Across L2 Instructional Settings (pp. 79104). New York: Rodopi. https://doi.org/10.1163/9789401208598_006

Toerien, M. (2013). "Conversation Analysis". In Vine, B. (Ed.). The Routledge Handbook of Language in the Workplace (pp. 15-26). New York: Routledge. 
Tollefson, J. W., \& Pérez-Milans, M. (Eds.). (2018). The Oxford Handbook of Language Policy And Planning. Oxford: Oxford University Press. https://doi.org/10.4324/9781315690001-3

Tracy, S. J. (2020). Qualitative Research Methods: Collecting Evidence, Crafting Analysis, Communicating Impact (Second edition). Hoboken: Wiley-Blackwell. https://doi.org/10.1093/oxfordhb/9780190458898.013.36

Tsuchiya, K. (2016). "Focusing on Content or Language?: Comparing Paired Conversations in CLIL and EFL Classrooms, Using a Corpus". In Romero Trillo, J. (Ed.). Yearbook of Corpus Linguistics and Pragmatics 2016 (pp. 179-201). Switzerland: Springer. https://doi.org/10.1007/978-3-319-41733-2_9

Tye-Murray, N. (2020). Foundations of Aural Rehabilitation: Children, Adults, and Their Family Members. San Diego: Plural Publishing.

Van Dijk, T. A. (2015). "Context". In Tracy, K. and Ilie C.\& Sandel T. (Eds.). The International Encyclopedia of Language and Social Interaction (pp.1-11). New Jersey: John Wiley \& Sons, Inc.

Van Lier, L. 1988. The Classroom and the Language Learner. Applied Linguistics and Language Study. London: Longman.

Wilkinson, S., \& Kitzinger, C. (2006). "Surprise as an interactional achievement: Reaction tokens in conversation”. Social Psychology Quarterly, 69(2), 150-182. https://doi.org/10.1177/019027250606900203

Wilkinson, S., Kitzinger, C., \& Weatherall, A. (2011). "Insertion Repair". Research on Language and Social Interaction, 44(1), 65-91. https://doi.org/10.1080/08351813.2011.544136

Wilkinson, S., Kitzinger, C., \& Rae, J. P., \& Rasmussen, G. (Eds.) (2020). Atypical Interaction the Impact of Communicative Impairments within Everyday Talk. Cham: Palgrave Macmillan. https://doi.org/10.1007/9783-030-28799-3

Wong, J., \& Waring, H. Z. (2010). Conversation Analysis and Second Language Pedagogy: A Guide for ESL/EFL Teachers. New York: Routledge. https://doi.org/10.4324/9780203852347

Wong, J., \& Waring, H. Z. (2021). Conversation Analysis and Second Language Pedagogy: A Guide for ESL/EFL Teachers (Second edition). New York: Routledge. https://doi.org/10.4324/9780429488023

Wooffitt, R. (2005). Conversation Analysis and Discourse Analysis: A Comparative and Critical Introduction. London: Sage. https://doi.org/10.4135/9781849208765

Yang, R. (2006). Repair in Web-based Conversation: A Case of Chinese Academic Discussion. Unpublished Doctoral Dissertation. Leicester: University of Leicester.

Yang, T. H. (2018). "The Use of Designedly Incomplete Utterance in TV Talk Shows". Working Papers in Applied Linguistics \& TESOL, 18(2), 33-48.

Young, R., \& He, A. W. (Eds.). (1998). Talking and Testing: Discourse Approaches to the Assessment of Oral Proficiency. Amsterdam: John Benjamins Publishing Company. https://doi.org/10.1075/sibil.14

Zhou, F. (2020). Models of the Human in Twentieth-Century Linguistic Theories: System, Order, Creativity. Singapore: Springer Nature Pte Ltd. https://doi.org/10.1007/978-981-15-1255-1

Zhu, J., \& Han, L. (2010). The Application of Context Theory in English Teaching of Reading. English Language Teaching, 3(1), 142-147. https://doi.org/10.5539/elt.v3n1p142

\section{Appendix: Transcription System}

Gail Jefferson's conversational analytic transcription system (2004: 24-31 cited in Jefferson et al. 2018: xi-xii)

\begin{tabular}{lll}
\hline $\mathrm{N}$ & Symbols & Brief description \\
\hline 1 & $=$ & Close talk together but not too much overlapped \\
\hline 2 & 0 & The symbol of encloses represent quiet talk \\
\hline 3 & underline & The symbol of underling under the words refer to "intonationally stressed" words \\
\hline 4 & CAPS & The capitalized letters refer to the production of words LOUDLY \\
\hline 5 & s::: & The colons indicates to the stretched production of sounds or words \\
6 & .hhh & Inbreathed production of sounds or words \\
\hline 7 & {[]} & Overlapped talk between some participants \\
\hline 8 & (word) & $\begin{array}{l}\text { Two parentheses surrounding some word (s) to refer to the uncertainty of the transcriber } \\
\text { in some the transcription of these words }\end{array}$ \\
\hline
\end{tabular}




\begin{tabular}{|c|c|c|}
\hline & ( ) & $\begin{array}{l}\text { Two Parentheses with no words to indicate to the transcriber is hearing something, but } \\
\text { he cannot figure it out }\end{array}$ \\
\hline 10 & (this/that) & Alternativeness in hearings \\
\hline 11 & ((description)) & $\begin{array}{l}\text { Descriptions of things, which are hardly to be represented by symbols such as mobile } \\
\text { phone ringing, shuffling papers, baby crying, etc. }\end{array}$ \\
\hline 12 & cu- & Cut-off in word or sound \\
\hline 13 & $(0.6)$ & Silence measured by seconds \\
\hline 14 & $()$. & "Silence of less than two tenths of a second" \\
\hline 15 & $\uparrow \downarrow$ & The arrows present the shift into higher or lower pitch than normal \\
\hline 16 & $\wedge$ & Alternative symbol represents the rise to high pitch \\
\hline 17 & $><$ & The talk within these symbols is speedy talk \\
\hline 18 & h & The letter $\mathrm{h}$ represents laughter \\
\hline 19 & wohhhrd & A combination of some $\mathrm{h}$ within a word is to represent breathiness \\
\hline 20 & (h) & $\begin{array}{l}\text { The letter } \mathrm{h} \text { with two parenthesis represent plosiveness of aspiration in talk such as talk } \\
\text { with breathlessness, laughter or crying, etc }\end{array}$ \\
\hline
\end{tabular}

\section{Copyrights}

Copyright for this article is retained by the author(s), with first publication rights granted to the journal.

This is an open-access article distributed under the terms and conditions of the Creative Commons Attribution license (http://creativecommons.org/licenses/by/4.0/). 